\title{
Dry Biosolids Reuse as Costless Biodegradable Adsorbent for Cadmium Removal from Water Systems
}

\author{
Tarek G. Ammari ${ }^{*}$, Majida Al-Hadidi', Noor Al-Kharabsheh', \\ Dima Khater', Saeid Abu-Romman ${ }^{3}$ \\ 1 Department of Water Resources and Environmental Management, Faculty of Agricultural Technology, \\ Al-Balqa Applied University, Al-Salt 19117, Jordan \\ 2 Department of Chemistry, Faculty of Science, Applied Science Private University, Amman 11931, Jordan \\ 3 Department of Biotechnology, Al-Balqa Applied University, Al-Salt 19117, Jordan \\ * Corresponding author's email: tarekamm@yahoo.com; tarek.ammari@bau.edu.jo
}

\begin{abstract}
The recycling of untreated dry biosolids, as costless biodegradable adsorbent for the removal of cadmium from aqueous phase was characterized. The adsorption of cadmium was reported to depend on initial $\mathrm{pH}$, adsorbent dose, agitation time, and initial Cd concentration. The results of the batch experiments revealed that the maximum adsorption capacity of the untreated dry biosolids was $39.22 \mathrm{mg} \mathrm{g}^{-1}$ under optimum operating conditions (i.e. $\mathrm{pH}$ : 5, adsorbent dose: $2 \mathrm{~g} \mathrm{l}^{-1}$, contact time: $16 \mathrm{~h}$ ). Adsorption reaches equilibrium after $16 \mathrm{~h}$, which can be attributed to both external surface adsorption $\left(R^{2}=0.86\right)$ and intraparticle diffusion $\left(R^{2}=0.98\right)$. The Langmuir isotherm model best described cadmium adsorption $\left(R^{2}=0.99\right)$ and the pseudo-second-order kinetic model was obeyed, suggesting that the mechanism involved was chemisorption. Biodegradability would make the recovery of adsorbed $\mathrm{Cd}$ an environmentally friendly process. Comparing the obtained findings with the related published results, it can be concluded that treating biosolids might be an unnecessary and costly procedure for recycling biosolids as an adsorbent for cadmium.
\end{abstract}

Keywords: adsorption, Cd-contaminated environment, untreated biosolids, intraparticle diffusion model, Langmuir isotherm model.

\section{INTRODUCTION}

Pollution of water systems with cadmium (Cd) can cause several environmental problems that might negatively impact human health as well as ecological systems (Wang and Chen, 2009). Cadmium can be discharged into the environment through its mining and smelting processes as well as by other anthropogenic means, such as the application of phosphate fertilizers, land application of biosolids, and diverse industrial uses, e.g. nickel-cadmium batteries.

According to Rahimzadeh et al. (2017), longlasting exposure to cadmium through air, water, soil, and food leads to cancer and organ system toxicity. A provisional tolerable weekly intake

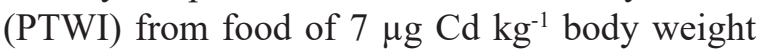

was identified by the WHO, which is equivalent to a daily tolerable intake level of 70 and $60 \mu \mathrm{g}$ $\mathrm{Cd}$ for the average $70-\mathrm{kg}$ man and $60-\mathrm{kg}$ woman, respectively (WHO, 1992).

The WHO has recommended a limit of $0.003 \mathrm{mg} \mathrm{dm}^{-3}$ as a drinking-water guideline value for cadmium based on an allocation of $10 \%$ of the PTWI to drinking-water (WHO, 1993).

Several materials have been investigated to remove cadmium ions from water systems by adsorption, including Arundo donax leaves, Cyperus laevigatus shoots, paper solid waste, and algal tissues (Hydrodictyon reticulatum) (Ammari, 2014; Ammari et al., 2015; Ammari, 2016; Ammari et al., 2017). Adsorption was considered in these studies for being inexpensive in addition to requiring minimum skills for implementation. 
Biosolids are a kind of colloidal sediment waste produced from the treatment of municipal wastewater. According to the German Corporation for International Cooperation (GIZ, 2020), there are about 31 domestic wastewater treatment plants in Jordan. Only one plant uses biosolids to generate energy. All the remaining treatment facilities do not utilize biosolids properly. Therefore, biosolids have become an ecological, environmental, and financial burden. In other parts of the world, biosolids are reused in landfilling, in forestry, in sea dumping, as soil improver, etc. (Ishikaw et al., 2007; El-Deen and Zhang, 2016). In addition, biosolids have been utilized to prepare useful adsorbing materials with prospective applications in environment using chemical (Rio et al., 2006; Ros et al., 2006; Anfruns et al., 2009; Nageeb et al., 2017) as well as physical activation methods (Otero et al., 2009; Monsalvo et al., 2011; AbdelAziz et al., 2017).

In the current study, (1) the adsorption performance of untreated dry biosolids (BS) was investigated in terms of cadmium removal from aqueous phase, (2) different key parameters including initial $\mathrm{pH}$, initial concentration, dose, and contact time were investigated to understand the adsorption of cadmium ions onto untreated dry biosolids collected from the Wastewater Treatment Plant of Wadi Shueib, and (3) adsorption kinetics and isotherm modeling were also discussed.

\section{MATERIALS AND METHODOLOGY}

\section{Preparation of the untreated dry biosolids}

Dry biosolids, brought from the Wastewater Treatment Plant of Wadi Shueib, were repetitively washed using tap water followed by distilled water. The purpose was to decrease the electrical conductivity of these samples to values around $100 \mu \mathrm{S} \mathrm{cm}^{-1}$, which were, further, dried in an oven at $105^{\circ} \mathrm{C}$. The oven-dried biosolids were ground with a ceramic mortar and pestle and sieved to obtain the particles between 250 and $355 \mu \mathrm{m}$ in size.

\section{Characterization of the BS}

\section{The Fourier transform infrared (FTIR) analyses}

The FTIR analyses using thermo Nicolet nexus 670 were carried out by using the $\mathrm{KBr}$ pellet technique, before and after adsorption, on the BS materials using the Fourier Transform Infrared Spectroscopy to define the functional groups involved in adsorbing $\mathrm{Cd}^{2+}$. The spectra of FTIR of BS were determined in a $400-4000 \mathrm{~cm}^{-1}$ spectral domain and a resolution of $4 \mathrm{~cm}^{-1}$.

\section{Energy dispersive $X$-ray spectrum (EDX)}

The EDX spectrum using Scanning Electron Microscope (SEM) (FEI quanta 600, Thermo Fisher) was conducted to reveal the elemental composition of the BS material. In this technique, the samples were excited by a highly focused, high-energy primary electron beam and X-rays are emitted from the samples.

\section{Thermogravimetric analysis}

The thermogravimetric analysis (TGA) and derivative thermogravimetry analysis (DTA) before and after adsorption were conducted to investigate the thermal characteristics of the BS material using a thermal analyzer (Netzsch STA $409 \mathrm{PG} / \mathrm{PC}$ ) with a heating rate of $10^{\circ} \mathrm{C} / \mathrm{min}$, under nitrogen flow at a rate of $30 \mathrm{ml} / \mathrm{min}$.

\section{Aqueous phase and analytical procedure}

Cadmium standard and aqueous solutions with concentrations ranging from 20 to $100 \mathrm{mg} \mathrm{l}^{-1}$ were prepared using a certified $\mathrm{Cd}$ reference solution (Cd metal in $2 \% \mathrm{HNO}_{3}$, USA). All solutions were prepared in $0.01 \mathrm{~mol} \mathrm{l}^{-1} \mathrm{NaNO}_{3}$ (UK). Diluted $\mathrm{NaOH}$ (Germany) or $\mathrm{HNO}_{3}$ (China) was used to modify the $\mathrm{pH}$ of these solutions. All chemicals were of analytical reagent grade. The flame atomic absorption spectrophotometer (A Varian model AA-6650 flame AAS, Shimadzu, Japan) was used to measure the concentrations of $\mathrm{Cd}$ in solutions at $228.8 \mathrm{~nm}$ wavelength.

\section{Adsorption experimental setup}

\section{Effect of solution $\mathrm{pH}$}

The solutions containing $20 \mathrm{mg} \mathrm{l}^{-1}$ of $\mathrm{Cd}$ and $2 \mathrm{~g} \mathrm{l}^{-1} \mathrm{BS}$ were used to investigate the effect of $\mathrm{pH}$ at the ambient temperature of the laboratory (approx. $25 \pm 1^{\circ} \mathrm{C}$ ). The initial $\mathrm{pH}$ of solutions was $2,3,4,5,6,7$, and 8 . The BS-Cd solutions were agitated on an orbit shaker for a period of $24 \mathrm{~h}$. This experiment was conducted in PE-bottles, previously washed with acid (Alemayehu and Lennartz, 2009) onto which no sorption of $\mathrm{Cd}$ was detected. 


\section{Effect of BS Dose}

Different doses of BS $\left(2,3\right.$, and $\left.4 \mathrm{~g} \mathrm{l}^{-1}\right)$ were added to the $\mathrm{pH} 5.0$ modified solutions of $100 \mathrm{mg}$ $1^{-1} \mathrm{Cd}$. The BS-Cd solutions were agitated for $16 \mathrm{~h}$.

\section{Effect of Contact Time}

The kinetics of the adsorption process were investigated by agitating the $\mathrm{pH} 5.0$ modified solutions that contain $20 \mathrm{mg} \mathrm{Cd}^{-1}$ and $2.0 \mathrm{~g} \mathrm{l}^{-1}$ BS for 1, 5, 30, 60, 180, 360, 960, 1200, and $1440 \mathrm{~min}$.

\section{Effect of Initial Concentrations of Cd}

The optimal adsorption conditions (in terms of $\mathrm{pH}$ and $\mathrm{BS}$ dose) were considered to study the effect of different initial concentrations of $\mathrm{Cd}$. Two $\mathrm{g}^{-1} \mathrm{BS}$ were added to the $\mathrm{pH} 5.0$ modified solutions of $20,40,60,80$, and $100 \mathrm{mg}^{-1} \mathrm{Cd}$.

The BS-Cd solutions were agitated for $16 \mathrm{~h}$, filtered via $0.45 \mu \mathrm{m}$ filters, and analyzed for the equilibrium concentration of $\mathrm{Cd}$ by flame AAS. The efficiency and capacity of adsorption were expressed using the following equations (Eqs. 1 and 2):

$$
\text { Removal efficiency }(\%)=\left[\left(C_{i}-C_{e}\right) / C_{i}\right] \cdot 100
$$

$$
q_{e}\left(m g g^{-1}\right)=\left[\left(C_{i-} C_{e}\right) \cdot V\right] / m
$$

where: $C i$ is the $\mathrm{Cd}$ initial concentration $\left(\mathrm{mg} \mathrm{l}^{-1}\right)$, $\mathrm{Ce}$ is the concentration of $\mathrm{Cd}$ at equilibrium ( $\left.\mathrm{mg} \mathrm{l}^{-1}\right)$,

$q_{e}$ is the capacity of adsorption at equilibrium in $\mathrm{mg} \mathrm{g}^{-1}$,

$V$ is the volume of Cd solutions in 1 , and $m$ is the BS weight in grams.

\section{Batch adsorption experimental data}

The Langmuir and Freundlich isotherm models; commonly available in the literature, were used to test the equilibrium data of $\mathrm{Cd}$ adsorption by BS. Isotherm variable parameters and determination coefficients $\left(R^{2}\right)$ were estimated from the linearization of the above-mentioned models.

\section{Langmuir Isotherm Model}

Cadmium adsorption can be described by the Langmuir model particularly as the Cd concentration at equilibrium $\left(\mathrm{C}_{\mathrm{e}}\right)$ becomes high (Essington, 2004). The Langmuir model is defined as (Eq. 3):

$$
q_{e}=\left(K_{L} q_{m} C_{e}\right) /\left(1+K_{L} C_{e}\right)
$$

where: $q e$ is the adsorbed $\mathrm{Cd}$ at equilibrium [mg g-1],

$K L\left(1 \mathrm{mg}^{-1}\right.$ of adsorbent) indicates the adsorption isotherm intensity (Essington, 2004) and

$q m$ is the monolayer adsorption capacity $\left(\mathrm{mg} \mathrm{g}^{-1}\right)$.

The Langmuir model is linearized as follows (Eq. 4):

$$
C_{e} / q_{e}=1 /\left(K_{L} q_{m}\right)+\left[\left(1 / q_{m}\right) \cdot C_{e}\right]
$$

A straight line is attained by plotting $\mathrm{C}_{\mathrm{e}} / q_{e}$ versus $\mathrm{C}_{\mathrm{e}}$ and $K_{L}$ and $q_{m}$ were computed. Slope and intercept of the straight line were used to estimate the values of $\mathrm{q}_{\mathrm{m}}$ and $K_{L}$, respectively. In addition, the affinity between the adsorbate and adsorbent can be predicted using the value of $R_{L}$, i.e. dimensionless separation factor (Hall et al., 1966). $R_{L}$ is expressed as (Eq. 5):

$$
R_{L}=1 /\left(1+K_{L} C_{0}\right)
$$

where: $K L$ is previously defined and $C o$ is the initial concentration of $\mathrm{Cd}\left(\mathrm{mg} \mathrm{l}^{-1}\right)$. When $R L$ is $0<R L<1$, adsorption is favorable (Weber and Chakravarty, 1974).

\section{Freundlich Isotherm Model}

The adsorption data over the whole range of $\mathrm{C}_{\mathrm{e}}$ can be described by the Freundlich isotherm model [20]. This model is given as (Eq. 6):

$$
q_{e}=K_{F} C^{1 / n}
$$

where: $K F$ and $1 / \mathrm{n}$ are the Freundlich constants that describe the capacity of sorption or the number of surface sites onto which adsorption might occur (Mustafa et al., 2004) and intensity of sorption, respectively.

The linearization of this model was carried out as follows (Eq. 7):

$$
\log q_{e}=\log K_{F}+(1 / n) \log C_{e}
$$

The variables of the Freundlich model were estimated by plotting $\log q_{e}$ against $\log C_{e}$. The slope and intercept of the straight line were used to calculate the values of $1 / \mathrm{n}$ and $\log K_{F}$, respectively. 


\section{Kinetics of adsorption}

Batch experiments were conducted to determine the equilibrium time using $100 \mathrm{mg}^{-1} \mathrm{Cd}$ initial concentration, $\mathrm{pH} 5.0$, and $2 \mathrm{~g}^{-1} \mathrm{BS}$ agitated for 1, 5, 30, 60, 180, 360, 960, 1200, and $1440 \mathrm{~min}$. According to Alyuz and Veli (2009), adsorption mechanism as either mass transfer or chemical reaction, can be determined by kinetic studies. In addition, estimating the rate of adsorption is useful for the design of batch adsorption systems. Type-1 pseudo-second-order kinetic model was applied to investigate the adsorption kinetics, which is described as (Eq. 8):

$$
t / q_{t}=\left(1 /\left(k_{2} q_{e^{2}}\right)\right)+t / q_{e}
$$

where: $\mathrm{k} 2\left(\mathrm{~g} \mathrm{mg}^{-1} \mathrm{~min}^{-1}\right)$ is the second-order adsorption rate constant calculated from the linear plot of $\mathrm{t} / \mathrm{q}_{\mathrm{t}}$ against $\mathrm{t}$.

Equations (9) and (10) were used to calculate the rate constant and the initial adsorption rate $\left(\mathrm{mg} \mathrm{g}^{-1} \mathrm{~min}^{-1}\right)$, respectively, and were as follows:

$$
k 2=1 /\left(\text { intercept } \cdot q_{e^{2}}\right)
$$

$$
\text { Initial adsorption rate }=k_{2} \cdot q_{e^{2}}
$$

The Intraparticle diffusion kinetic model was also applied to fit the present kinetic data, which is described as (Eq. 11):

$$
q_{t}=K_{d i t} t^{.5}+C
$$

where: $K d i$ is the rate constant $\left(\mathrm{mg} / \mathrm{g} \min ^{1 / 2}\right)$ (Weber and Morris, 1963).

\section{RESULT AND DISCUSSION}

\section{Characterization of BS}

\section{Energy dispersive $X$-ray spectrum}

The EDX analysis showed that before $\mathrm{Cd}$ adsorption, BS consists mainly of carbon (percent by mass $=94.65$ wt. $\%$ ) and traces of $\mathrm{Si}, \mathrm{S}, \mathrm{Mg}$, $\mathrm{Ca}$, and $\mathrm{P}$ (Fig. 1). The appearance of the main characteristic peaks of $\mathrm{Cd}$ in the EDX spectrum of the BS sample after Cd adsorption shown in Figure 1 reveals that $\mathrm{Cd}$ ions have been successfully adsorbed onto BS.

\section{Thermogravimetric analysis}

The TGA and DTG for BS before and after $\mathrm{Cd}$ adsorption are shown in Figure 2 (a) and (b); respectively. The thermogravimetric profiles showed that $\mathrm{Cd}^{2+}$ adsorption caused delay in thermal degradation. In general, the mass losses occur in four phases. The first phase was observed approximately between $50^{\circ} \mathrm{C}$ and $175^{\circ} \mathrm{C}$, in which the release of superficial absorbed water, coordinated water and possible volatile compounds occurred (Conesa et al., 1997; Masoud and Ali, 2015). The second and third phases ranged from $200^{\circ} \mathrm{C}$ to $540^{\circ} \mathrm{C}$ and were attributed to the thermal degradation of organic matter such as semivolatile compounds, cellulose, and other organic polymers in the BS. The last phase started above $660^{\circ} \mathrm{C}$, which according to Font et al., (2001), Weber et al., (2008), and Patricia et al., (2009), is associated with the decomposition of non-biodegradable polymers and possible minerals in the sample. The estimated total mass losses at $900^{\circ} \mathrm{C}$

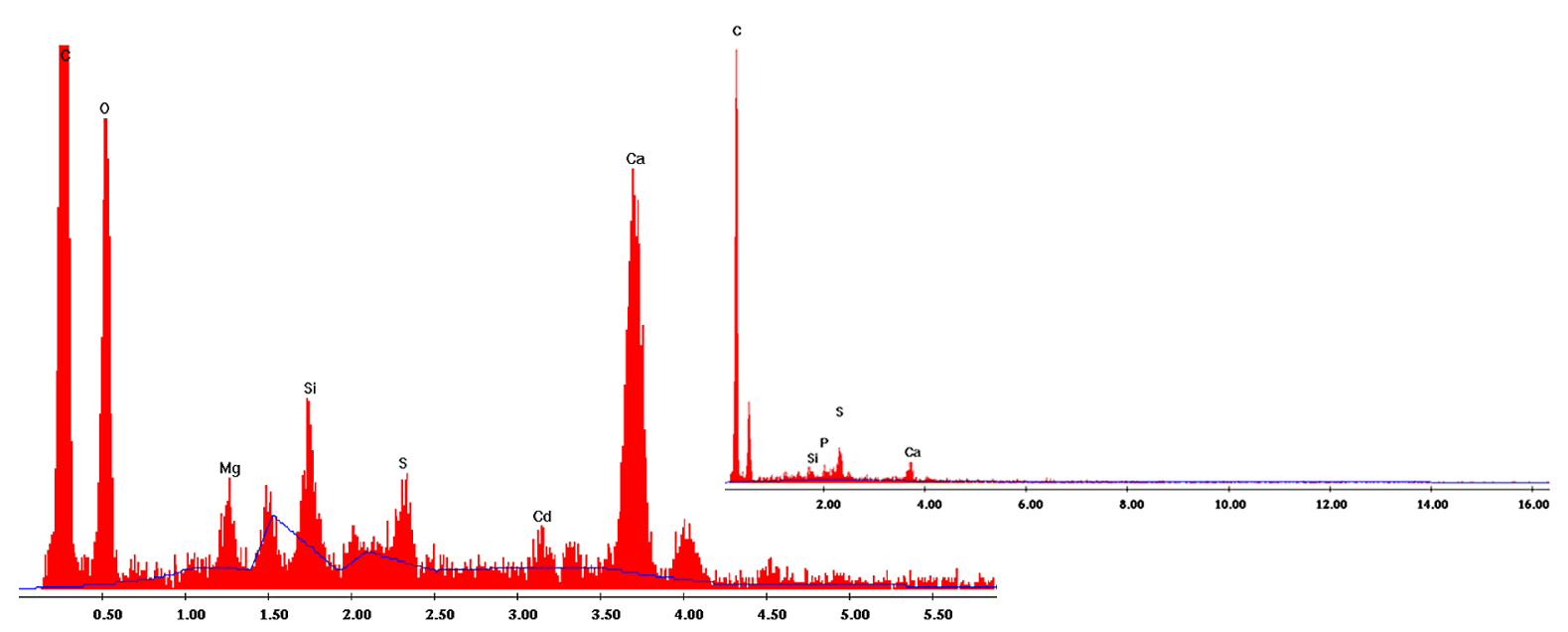

Fig. 1. EDX spectra of BS before (the left figure) and after Cd adsorption 
were $67.7 \%$ and $60.9 \%$ before and after adsorption, respectively. The DTA curve of BS before adsorption showed a peak at around $125^{\circ} \mathrm{C}$ that is associated with water loss (Figure 2); whereas the position of this peak shifted to $105^{\circ} \mathrm{C}$ and its intensity decreased after $\mathrm{Cd}$ adsorption because $\mathrm{Cd}$ ions repelled the water molecules occupied by the BS.

\section{Effect of $\mathrm{pH}$}

The ionization of functional groups increases along with the solution $\mathrm{pH}$, consequently, the surface negative charges of certain adsorbents increase as well (Chen and Ting, 1995). Moreover, the solution chemistry of heavy metals can be influenced by the solution $\mathrm{pH}$ via hydrolysis (Wang, 2002).

Adsorption of cadmium onto BS, as affected by solution $\mathrm{pH}$ was examined by modifying the initial solution $\mathrm{pH}$ to $2,3,4,5,6,7$, and 8 . Such $\mathrm{pH}$ values were selected because they might be found in municipal as well as industrial wastewater (Bond and Straub, 1974). The solutions were prepared using $0.01 \mathrm{MNaNO}_{3}$ was to simulate the actual conditions of most water systems because the ionic strength of background solutions reflects the interaction degree among ions in solutions (Sparks, 1995).

The $\mathrm{pH}$-adsorption edges of Cd (II) obtained for the BS are shown in Figure 3. The results showed that the $\mathrm{Cd}$ removal efficiency ranged from $13.7 \%$ to $95.3 \%$ at $\mathrm{pH} 2$ and 5, respectively. The obtained results are commonly in agreement with the previously published studies for sewage sludge ash (pH 6) (Elouear et al., 2009), for treated sewage sludge ( $\mathrm{pH} \mathrm{6)}$ (Ait Ahasainea et al., 2017), for modified physically activated sewage sludge (Nageeb et al., 2018).

According to Hawari and Mulligan (2006) the heavy metal removal can be attributed to different causes such as (1) electrostatic attraction, (2) formation of surface complexes, and (3) precipitation. The obtained results showed that, at $\mathrm{pH} 2$, the efficiency of $\mathrm{Cd}$ removal was lower than that at higher $\mathrm{pH}$. At $\mathrm{pH} 2$, the $\mathrm{H}^{+}$concentration increased and occupied almost all adsorption sites on the surface of the adsorbent, which limited the ability of $\mathrm{Cd}$ ions to move towards the surface due to charge repulsion. Protons also decrease the negative charges by protonation, i.e., association of the functional group with protons (Khalfa and Bagane, 2011). The removal percentage increases along with the $\mathrm{pH}(>2)$, due to the decrease of $\mathrm{H}^{+}$on the surface, which results in lesser repulsion with Cd ions (Sheha and El-Zahhar, 2008). Moreover, the surface becomes progressively negatively charged, as the hydroxyl ion activity (and $\mathrm{pH}$ ) increase, thus creating favorable conditions for specific adsorption of $\mathrm{Cd}$ (Zhou and Haynes, 2010).

Furthermore, the divalent $\mathrm{Cd}$ and $\mathrm{Cd}(\mathrm{OH})^{+}$ are the dominant $\mathrm{Cd}$ species at $\mathrm{pH}$ less than 8 (Babic et al., 2002, Cordero et al., 2004). For the chemical composition of solutions used in our study, the free divalent $\mathrm{Cd}$ ranged from $97.3 \%$ of the total concentration of $\mathrm{Cd}$ at $\mathrm{pH} 8$ to $\approx 98 \%$ at pH 2 as estimated by Visual MINTEQ (Data not shown). The obtained results agreed with Baes and Mesmer (1986) and Srivastava et al. (2006) who reported that the $\log K$ of Cd hydrolysis reaction is equal to -10.08 or -7.9 , respectively. Therefore, when $\mathrm{pH}$ is less than $\mathrm{pKa}$, free divalent $\mathrm{Cd}$ ions are dominant in solutions. Consequently, $\mathrm{Cd}$ speciation, as affected by $\mathrm{pH}$, was not responsible for the observed "adsorption envelope". It can be concluded that the magnitude of adsorption in the current study can be attributed to the functional groups and their associated ionic state. Ait Ahsainea et al. (2017) suggested that, among others, the $-\mathrm{OH}$ stretching vibration and the stretching
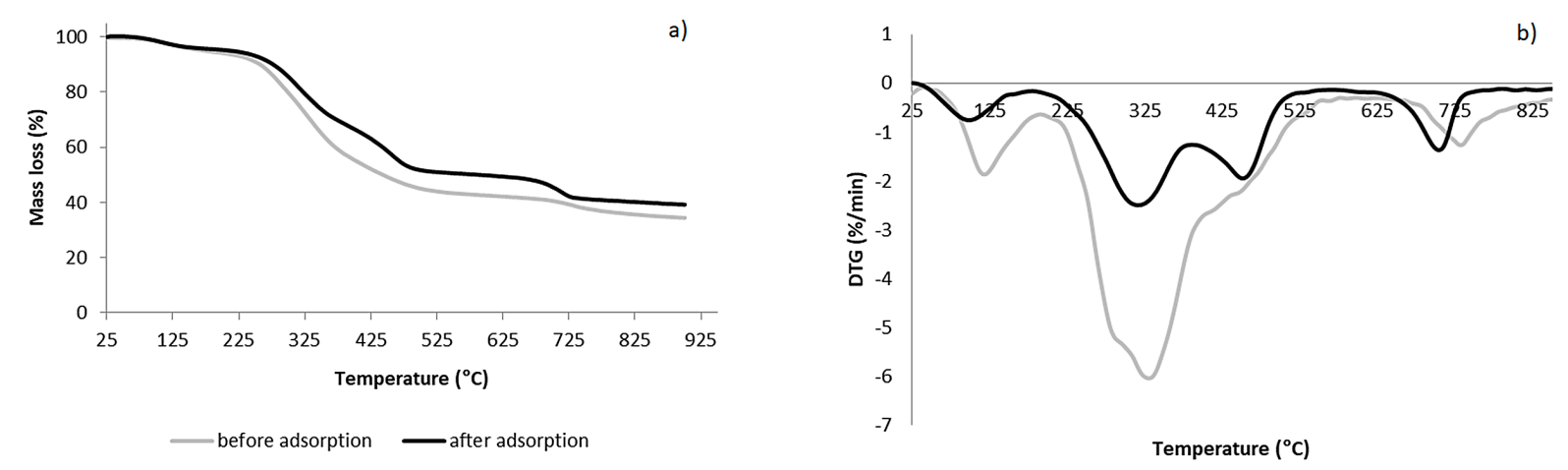

Fig. 2. a) TG and b) DTG thermograms for the BS before and after Cd adsorption 
of the N-H bond of organic compounds can be responsible for the adsorption of $\mathrm{Cd}^{2+}$ by mesoporous treated sewage sludge. The FTIR spectra analysis of Li et al. (2018) showed that Cd (II) adsorption by live and dead biosorbents took place via the hydroxyl, amino, amide, carbonyl, and carboxyl groups. These candidate functional groups were determined by the FTIR spectra of the BS before and after adsorption (Figure 4). The peaks at 3,390, 2922 and 2852, 1,652, and $1,542 \mathrm{~cm}^{-1}$ are associated with several organic functional groups. The peak at $3,390 \mathrm{~cm}^{-1}$ is attributed to the $-\mathrm{OH}$ stretching vibration (Droussi et al., 2009) associated with cellulose in the BS, adsorbed water molecules (Vazquez et al., 2009), and the stretching of the $\mathrm{N}-\mathrm{H}$ bond of organic compounds (Vazquez et al., 2009; El-Deen and Zhang, 2016). The peaks at 2922 and $2852 \mathrm{~cm}^{-1}$ are attributed to $\mathrm{C}-\mathrm{H}$ stretching (Belfer et al., 2000); whereas, the peaks at 1,652 and $1,542 \mathrm{~cm}^{-1}$ indicated the existence of amide $\mathrm{I}(-\mathrm{CO}-$ stretching vibration) and amide II (-NH bending and $-\mathrm{CN}$ stretching) in proteins, respectively. After

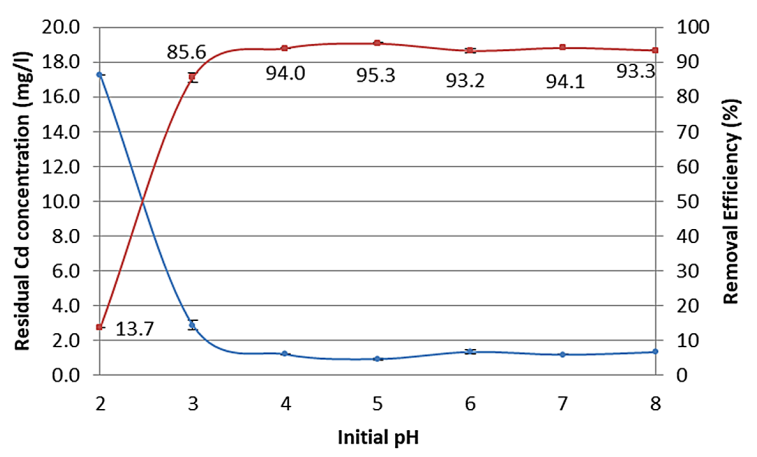

Fig. 3. Residual concentration of $\mathrm{Cd}$ and removal efficiency of BS as affected by $\mathrm{pH}$ (Adsorbent dose was $100 \mathrm{mg}$, concentration of Cd was $20 \mathrm{mg} \mathrm{l}^{-1}$, I was $0.01 \mathrm{M}$, contact time was $24 \mathrm{~h}, \mathrm{n}=3$, and error bars represent standard deviation) adsorption, while some peaks disappeared, shifts were observed for the peaks from 3,390 and $1,652 \mathrm{~cm}^{-1}$ to 3,448 and $1,639 \mathrm{~cm}^{-1}$, respectively, indicating that the above-mentioned functional groups might be involved in the adsorption of $\mathrm{Cd}$ ions. However, the increase of the band intensity observed in the region of the - $\mathrm{OH}$ stretching vibration when compared with the BS before adsorption could be due to the adsorbed water after adsorption. Additionally, the other bands in the region $200-2,600 \mathrm{~cm}^{-1}$ were relatively found to decrease in intensity after adsorption. According to Ait Ahsainea et al. (2017), this might be due to the electrostatic interactions between the related functional groups $(-\mathrm{NH}$ and $-\mathrm{CO})$ and $\mathrm{Cd}$ ions, which is in agreement with (Mnahan, 1999a; Mnahan, 1999b; Gutierrez-Segura et al., 2012). Shift and disappearance of peaks suggest a binding between $\mathrm{Cd}$ ions and the BS surface. It can also be concluded that hydroxyls and amides are the most important characteristic functional groups in the $\mathrm{BS}$ participating in $\mathrm{Cd}^{2+}$ adsorption.

\section{Effect of BS Dose}

The effect of BS dose on Cd adsorption was investigated and presented in Figure 5. The results showed that the removal efficiency of $\mathrm{Cd}$ increased along with the BS dose from 2 to $4 \mathrm{~g}$ $1^{-1}$ (Figure 5). At the highest dose, the detected increase in Cd removal (\%) is due to the increased surface area of the adsorbent and adsorption locations. Nevertheless, the reduction in the capacity of adsorption with the increase of BS dose (from 35.4 to $21.9 \mathrm{mg} \mathrm{g}^{-1}$ ) can be attributed to the unsaturation of binding locations via the process of adsorption (Ghodbane et al., 2008). Another reason can be due to the aggregation of particles resulting from high adsorbent concentration. Such aggregation would result in reduced the total
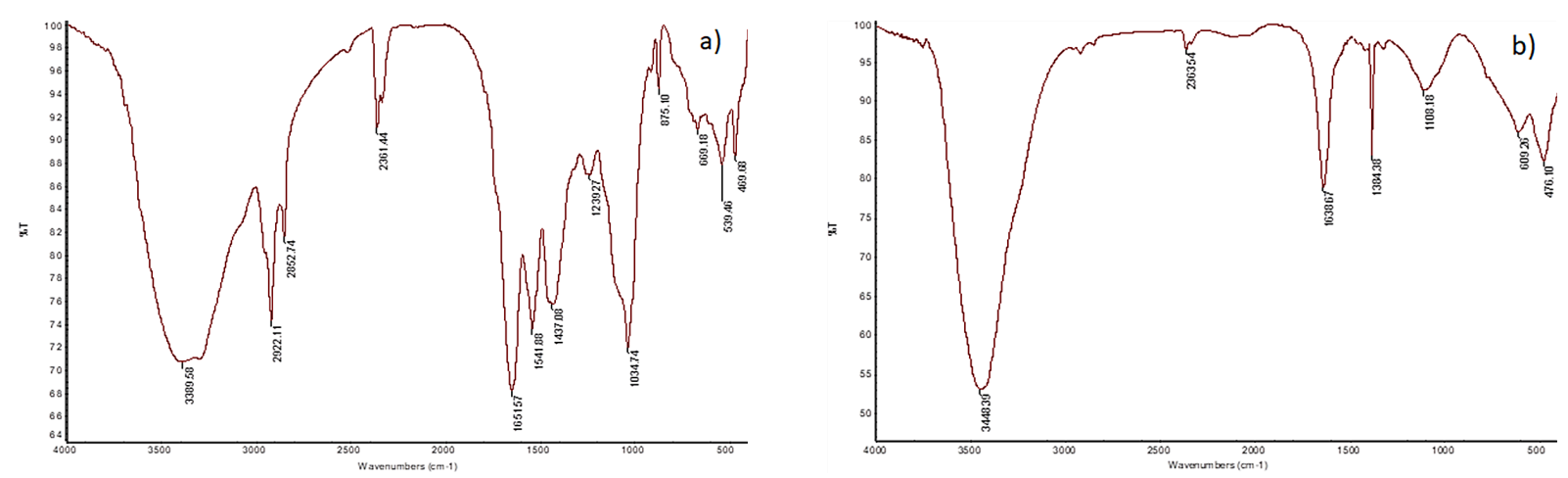

Fig. 4. FTIR spectra for BS: a) before and b) after adsorption 
surface area of the adsorbent and increased diffusion path length (Zhai et al., 2004). Rao et al. (2008) found that the $\mathrm{Cd}$ adsorption increased along with the dose of activated sewage sludge. Hammaini et al. (2007) also showed that adsorption capacity for $\mathrm{Cd}$ varied with the activated sludge (biomass) dose.

\section{Adsorption kinetics study}

\section{Effect of contact time}

The binding of $\mathrm{Cd}$ ions on the BS as a function of contact time was investigated under optimum experimental conditions (Figure 6). Cadmium adsorption increased along with contact time and its removal efficiency gradually reached a constant value of $81 \%\left(40.4 \mathrm{mg} \mathrm{g}^{-1}\right)$ after $16 \mathrm{~h}$ (Figure 6). The obtained results agree well with earlier published data concerning the relatively long equilibrium times. Luo et al. (2006) reported that the adsorption of $\mathrm{Cu}$ onto activated sewage sludge was up to $90 \%$ after 0.5 hour, whereas the adsorption of Cd was up to $96 \%$ after a time of 7 hours. Rashed (2006) found that the adsorption of $\mathrm{Pb}$ by the stones of peach and apricot increased with contact time and reached the maximum value at 3 and 4 hours, respectively. Fonseca et al. (2006) showed that the equilibrium times for manganese and cadmium onto vermiculite were 48 and 72 hours, respectively.

\section{Kinetics of adsorption}

The adsorption kinetics provide important information about the sorption mechanism (Bulgariu and Bulgariu, 2014). The kinetics of the adsorption of Cd by BS was explored by plotting $\mathrm{t} /$ $q_{t}$ versus $t$ (Figure 7). One of the commonly used

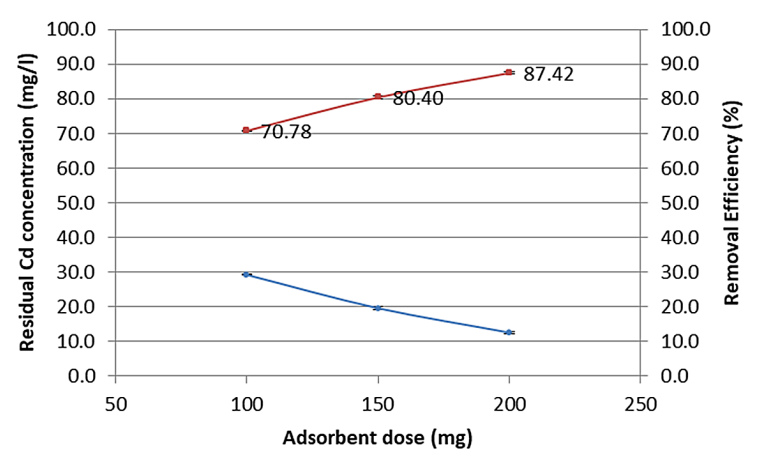

Fig. 5. Remaining Cd concentrations as affected by adsorbent dose (Contact time was $16 \mathrm{~h}$, initial $\mathrm{pH}$ as 5.0, Cd concentration was $100 \mathrm{mg} \mathrm{l}^{-1}$, I was $0.01 \mathrm{M}$, $\mathrm{n}=3$, and error bars represent standard deviation) kinetic models is the pseudo-second-order model. This model implies that the chemical interactions among ions of $\mathrm{Cd}$ and surface functional groups of the BS is involved, which is the rate controlling step. The agreement between the experimental and predicted values of the model was reflected by the $R^{2}$ (determination coefficient very close to 1) (Table 1), which indicates that such kinetic model effectively describes the $\mathrm{Cd}$ adsorption kinetics onto BS (Figure 7 and Table 1). This model indicates that chemisorption, which comprises sharing or exchange of electrons between the BS and the adsorbate ions, is the rate limiting step (Ho and McKay, 1999). From Figure 7, the estimated $\mathrm{q}_{\mathfrak{e}}$, was calculated for the initial concentration of $\mathrm{Cd}$ of $100 \mathrm{mg} \mathrm{l}^{-1}$ as shown in Table 1. The value of the calculated $\mathrm{q}_{\mathrm{e}}$ agrees well with the experimental value $\left(R^{2}=0.99\right)$. Similar results were reported for different adsorbents (Hawari and Mulligan, 2006; Zhou and Haynes, 2010; Ammari, 2014; Ammari et al., 2015; Ammari, 2016; Ammari et al., 2017; Ma et al., 2018).

The Weber-Morris relationship ( $q_{t}$ vs. $\left.t^{1 / 2}\right)$ was applied to better understand the mechanism of diffusion (Kalavathy et al., 2005; Sheha and El-Zahhar, 2008). The plot in Figure 7 indicates a multilinear characteristic and the intraparticular diffusion rate $\left(K_{d i}\right)$ and $C$ were calculated (Table 1). It can be seen that there are two steps that control the adsorption process: (1) the first step shows mass transfer of the Cd ions from the liquid to the solid external surface known as boundary layer diffusion and (2) the second step is the intraparticle diffusion; the movement of $\mathrm{Cd}$ ions within the pores begins and the equilibrium is established. Similar results were reported by Ait Ahsainea et al. (2017) who found that the adsorption

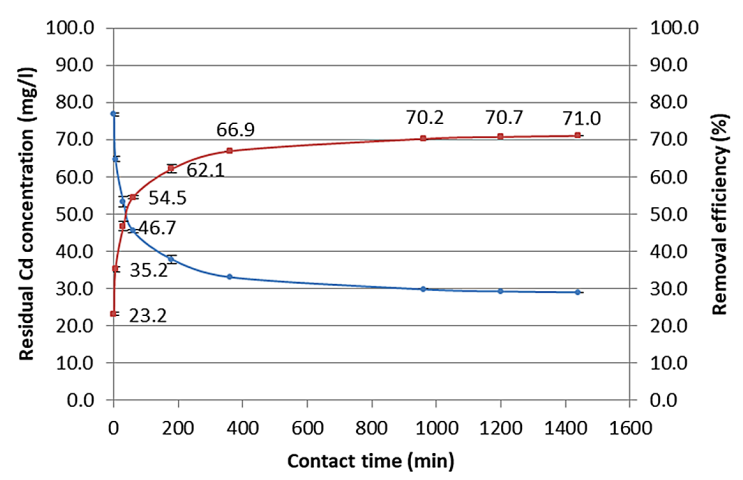

Fig. 6. Remaining Cd concentration as affected by agitation time (Adsorbent dose was $100 \mathrm{mg}$, initial $\mathrm{pH}$ as 5.0, Cd concentration was $100 \mathrm{mg} \mathrm{l}^{-1}$, I was 0.01 $\mathrm{M}, \mathrm{n}=2$, and error bars represent standard deviation) 
of $\mathrm{Cd}$ ions onto the mesoporous treated sewage sludge is a combination of these two phases as rate-controlling steps. Such results might explain the relatively long equilibrium time obtained in the current study (16h). It might be reasonable to conclude that the intraparticle diffusion of $\mathrm{Cd}$ ions within the pores was evidently slow, which might delay attaining the equilibrium state.

\section{Adsorption Isotherm Study}

Specific adjustable parameters can characterize the adsorption isotherms. Such parameters describe the properties of the adsorbent surface and the affinity of the adsorbent to the adsorbed ions. As the concentration of $\mathrm{Cd}$ increased from 20 to $100 \mathrm{mg} \mathrm{l}^{-1}$, a decrease in the Cd removal percentage by BS from $96.2 \%$ to $71.2 \%$ was observed, which is due to the saturation of adsorption sites on the BS when the $\mathrm{Cd}$ concentration exceeds a certain value, as explained by Semerjian (2010).

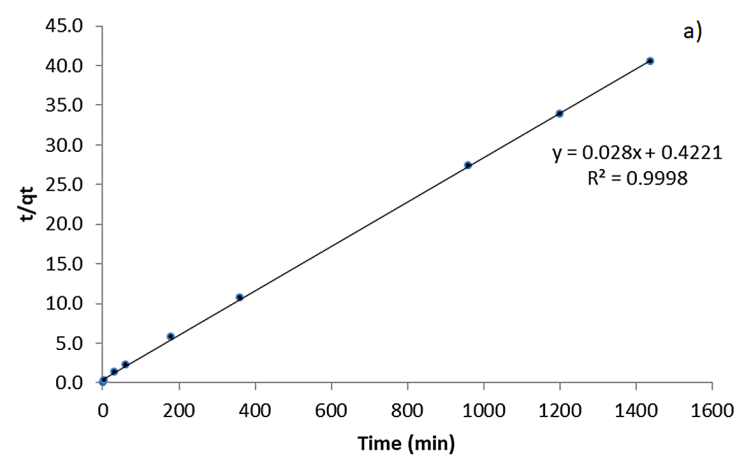

When equilibrium is attained, $q_{e}$ of BS increased along with concentration of $\mathrm{Cd}$ in the solution (from 20 to $100 \mathrm{mg} \mathrm{l}^{-1}$ ). These findings agree with the previously reported results of various studies (Elouear et al., 2009; Ammari, 2014; Ammari et al., 2015; Ammari, 2016; Ammari et al., 2017). With increasing initial concentrations of $\mathrm{Cd}$, the observed increase in $\mathrm{Cd}$ ions adsorbed onto the BS can be due to the greater concentration gradient resulting from more $\mathrm{Cd}(\mathrm{II})$ available in the solution at greater concentrations of $\mathrm{Cd}$. In the present study, the relation between the capacity of adsorption and the concentration of $\mathrm{Cd}$ at equilibrium were described and characterized by the Langmuir and Freundlich isotherm models. These isotherms are simple and able to characterize the adsorption process at the solidsolution interface. The isotherms data can be employed in designing the adsorption systems (Saygiderger et al., 2005). The constants and $R^{2}$ of the Langmuir and Freundlich isotherms are reported in Table 1 . The results revealed that

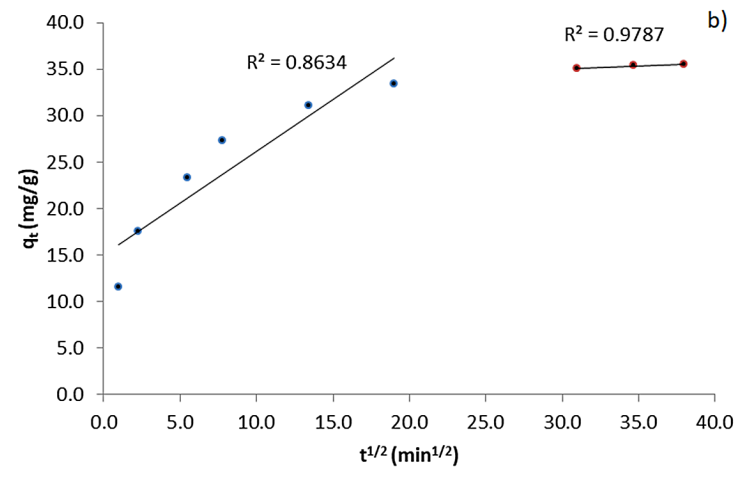

Fig. 7. Adsorption kinetics onto BS tested with: a) the pseudo-second-order kinetic model and b) the intraparticle diffusion kinetic model

Table 1. Effect of initial Cd concentration (20-100 $\left.\mathrm{mg} \mathrm{l}^{-1}\right)$ and $2 \mathrm{~g} \mathrm{l}^{-1}$ adsorbent dose on equilibrium adsorption capacity at $\mathrm{pH} 5.0$ and $0.01 \mathrm{MNaNO}_{3}$, the kinetic parameters for pseudo-second-order kinetic model and isotherm adjustable parameters of $\mathrm{Cd}$ adsorption on $\mathrm{BS}$

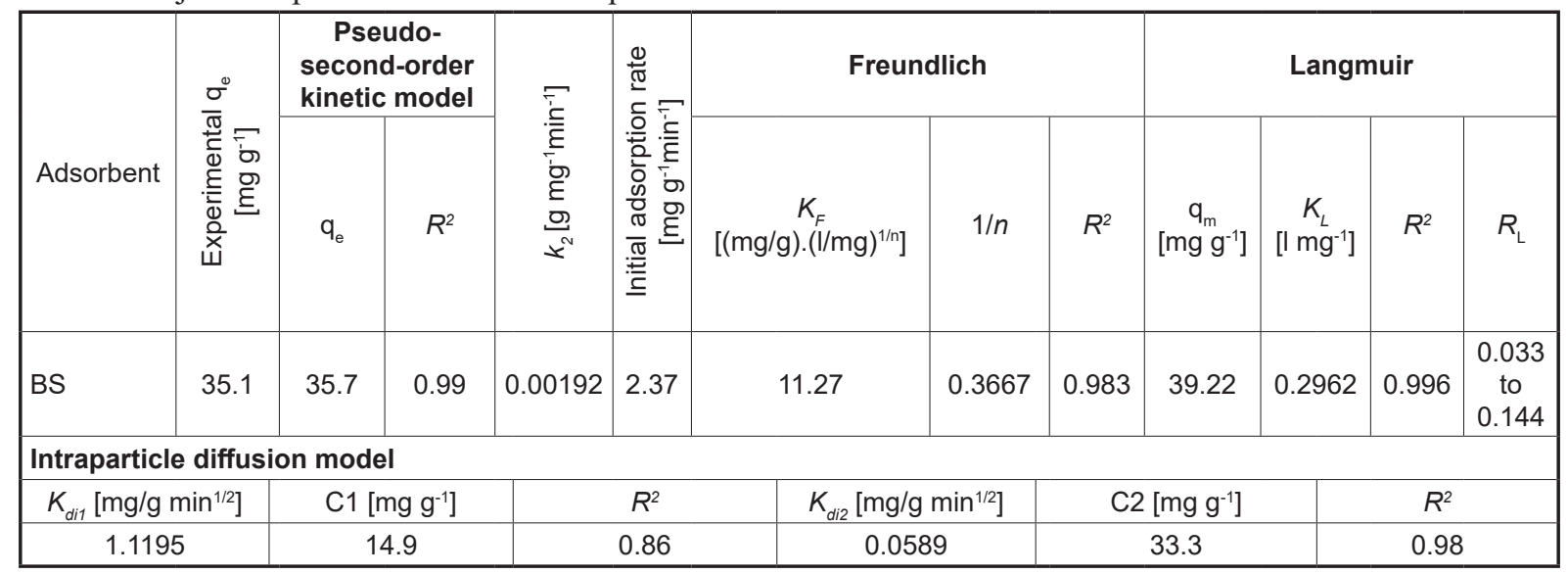



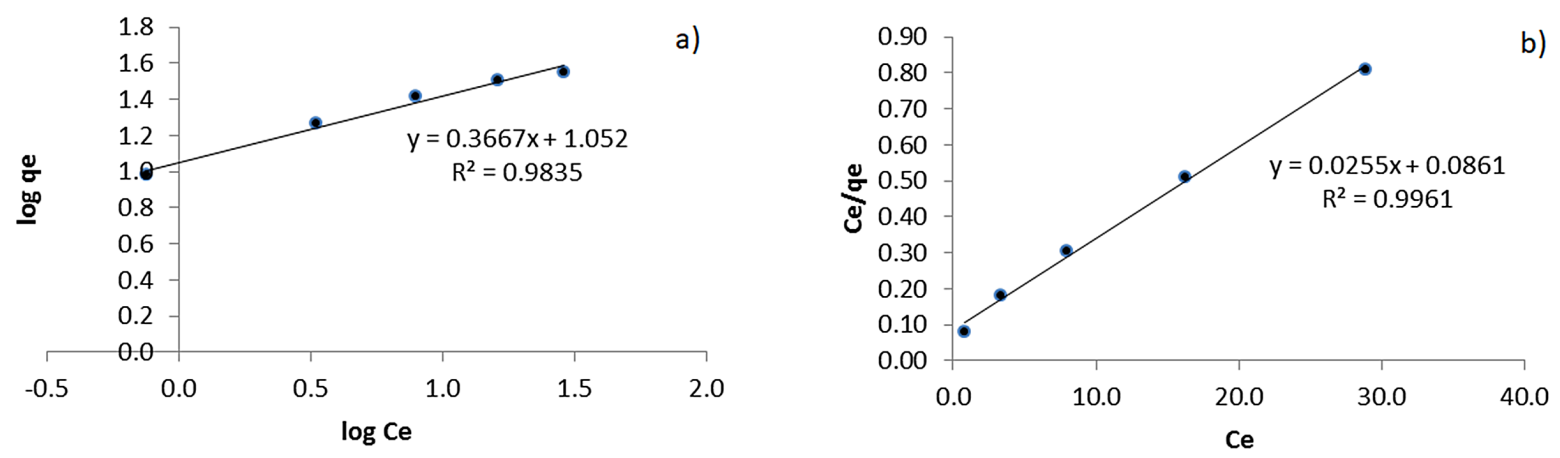

Fig. 8. a) Linearized Freundlich isotherm and b) linearized Langmuir isotherm of the BS

adsorption of Cd onto the BS better followed the Langmuir than the Freundlich isotherm model (Figure 8), indicating that the adsorption of $\mathrm{Cd}$ onto BS occurred on the adsorption sites; i.e. functional groups, as a monolayer adsorption. The maximum monolayer adsorption capacities $\left(\mathrm{q}_{\mathrm{m}}\right)$ of Cd calculated from the Langmuir model were $39.22 \mathrm{mg} \mathrm{g}^{-1}$ (Table 1). Moreover, the critical characteristic of the Langmuir model, $R_{L}$, a dimensionless constant referred to as equilibrium parameter is reported in Table 1 . The calculated $R_{L}$ values range between 0 and 1 , which refer to a favorable adsorption process.

A comparison of the values found in our study (39.22 $\left.\mathrm{mg} \mathrm{g}^{-1}\right)$ with commercial activated carbon (8.21 $\mathrm{mg} \mathrm{g}^{-1}$ ) (Azouaou et al., 2010); sewage sludge ash (7.1 $\mathrm{mg} \mathrm{g}^{-1}$ ) (Elouear et al., 2009) ; iron oxide coated sewage sludge $\left(14.7 \mathrm{mg} \mathrm{g}^{-1}\right)$ (Phuengpraso et al., 2011); modified physically activated sewage sludge (31.44 $\mathrm{mg} \mathrm{g}^{-1}$ ) (Nageeb et al., 2018); mesoporous treated sewage sludge (56.2 $\mathrm{mg} \mathrm{g}^{-1}$ ) (Ait Ahsainea et al., 2017) revealed that the BS presented a reasonable $\mathrm{Cd}$ adsorption capacity from liquid phase without any kind of treatment or modification. The disposal of loaded BS with $\mathrm{Cd}$ ions could impose an environmental issue (Gaballah et al., 1998). Commonly, the regeneration of exhausted adsorbent materials is carried out through the desorption process, which was reported for inorganic sorbents (e.g. montmorillonite and silica gel as reported by Katsumata et al. (2003) as well as biosorbents (Abu Al-Rub et al., 2004; Bulgariu and Bulgariu, 2014). The regeneration of loaded biosolids for reuse might not be feasible or necessary because such material is increasingly generated, whereas the recovery of $\mathrm{Cd}$ from loaded biosolids is of environmental and industrial importance.

\section{CONCLUSIONS}

We found that dry biosolids can be recycled as costless biodegradable adsorbent for cadmium removal from polluted water systems. The removal of $\mathrm{Cd}$ considerably depends on the initial $\mathrm{Cd}$ concentration, agitation time, dose, and solution $\mathrm{pH}$. The adsorption of $\mathrm{Cd}$ ions onto BS was characterized by the Langmuir isotherm and the pseudo-second-order model. The maximum capacity of adsorption was $39.22 \mathrm{mg} \mathrm{g}^{-1}$ under optimal experimental conditions. Equilibrium was attained after $16 \mathrm{~h}$.

Comparing our findings with the related published results, treating biosolids both chemically or physically will increase the cost of biosolids recycling and might not be necessary. We showed that the adsorption capacity of untreated BS is greater than or, at least, comparable to that of commercial activated carbon, sewage sludge ash, iron oxide coated sewage sludge, modified physically activated sewage sludge, and mesoporous treated sewage sludge. Such findings will help reducing the sewage sludge recycling costs. In addition, biodegradability would make the recovery of adsorbed $\mathrm{Cd}$ an environmentally friendly process.

\section{REFERENCES}

1. Abdel Aziz M., Bassyouni M., Soliman M.F., Gutub S.A., Magram S.F. (2017). Removal of heavy metals from wastewater using thermally treated sewage sludge adsorbent without chemical activation. Journal of Materials and Environmental Science, 8(5), 1737-1747.

2. Abu Al-Rub F.A., El-Naas M.H., Benyahia F., Ashour I. (2004). Biosorption of nickel on blank alginate beads, free and immobilized algal cells. Process Biochemistry, 39, 1767-1773. 
3. Ait Ahsainea H., Zbair M., El Haouti R. (2017). Mesoporous treated sewage sludge as outstanding low-cost adsorbent for cadmium removal. Desalination and Water Treatment, 85, 330-338.

4. Alemayehu E., Lennartz B. (2009). Virgin volcanic rocks: kinetics and equilibrium studies for the adsorption of cadmium from water. Journal of Hazardous Materials, 169, 395-401.

5. Alyuz B., Veli S. (2009). Kinetics and equilibrium studies for the removal of nickel and zinc from aqueous solutions by ion exchange resins. Journal of Hazardous Materials, 167, 482-488.

6. Ammari T.G. (2014). Utilization of a natural ecosystem bio-waste; leaves of Arundo donax reed, as a raw material of low-cost eco-biosorbent for cadmium removal from aqueous phase. Ecological Engineering, 71, 466-473.

7. Ammari T.G. (2016). Performance of unmodified paper solid waste for cadmium removal from aqueous phase; equilibrium and kinetic studies. Chemical Engineering Communications, 203, 831-839.

8. Ammari T.G., Al-Labadi I., Tahboub T., Ghrair A. (2015). Assessment of unmodified wetland biowaste: Shoots of Cyperus laevigatus, for cadmium adsorption from aqueous solutions. Process Safety and Environmental Protection, 95, 77-85.

9. Ammari T.G., Al-Atiyat M., Abu-Nameh E.S., Ghrair A., Jaradat D., Abu-Romman S. (2017). Bioremediation of cadmium-contaminated water systems using intact and alkaline-treated alga (Hydrodictyon reticulatum) naturally grown in an ecosystem. International Journal of Phytoremediation, 19(5), 453-462.

10. Anfruns A., Canals Batlle C., Ros A., Lillo Rodenas M.A., Linares Solano A., Fuente E., Montes-Moran M.A., Martin M.J. (2009). Removal of odourcausing compounds using carbonaceous adsorbents/ catalysts prepared from sewage sludge. Water Science and Technology, 59(7), 1371-1376.

11. Azouaou N., Sadaouia Z., Djaafri A., Mokaddem H. (2010). Adsorption of cadmium from aqueous solution onto untreated coffee grounds: equilibrium kinetics and thermodynamics. Journal of Hazardous Materials, 184, 126-134.

12. Babic B., Milonjic S., Polovina M., Cupic S.O., Kaludjerovic B. (2002). Adsorption of zinc, cadmium and mercury ions from aqueous solutions on an activated carbon cloth. Carbon, 40, 1109-1115.

13. Baes C.F., Mesmer R.E. (1986). The hydrolysis of cations, New York: John Wiley and Sons.

14. Belfer S., Fainchtain R., Purinson Y., Kedem O. (2000). Surface characterization by FTIR-ATR spectroscopy of polyethersulfone membranes unmodified modified and protein fouled. Journal of Membrane Science, 172, 113-124.
15. Bond R.G., Straub C.P. (1974). CRC Hand book of environmental control, vol. 4. Wastewater, Treatment and Disposal. Boca Raton (FL): CRC Press.

16. Bulgariu L., Bulgariu D. (2014). Enhancing biosorption characteristics of marine green algae (Ulva lactuca) for heavy metals removal by alkaline treatment. Journal of Bioprocessing and Biotechniques, 4, 146, http://dx.doi.org/10.4172/2155-9821.1000146.

17. Chen P., Ting Y.P. (1995). Effect of heavy metal uptake on the electrokinetic properties of Saccharomyces cerevisiae. Biotechnology Letters, 17 (1), 107-112.

18. Conesa J.A., Marcilla A., Prats D., RodriguezPastor M, (1997). Kinetic study of the pyrolysis of sewage sludge. Waste Management and Research, 15 (3), 293-305.

19. Cordero B., Lodeiro P., Herrero R., Vicente E. (2004). Biosorption of cadmium by Fucus spiralis. Environmental Chemistry, 3, 180-187.

20. Droussi Z., D’orazio V., Provenzano M.R., Hafidi M., Ouatmane A. (2009). Study of the biodegradation and transformation of olive-mill residues during composting using FTIR spectroscopy and differential scanning calorimetry. Journal of Hazardous Materials, 164, 1281-1285.

21. El-Deen S.E.A.S., Zhang F. S. (2016). Immobilisation of TiO2-nanoparticles on sewage sludge and their adsorption for cadmium removal from aqueous solutions. Journal of Experimental Nanoscience, 11, 239-258.

22. Elouear Z., Bouzid J., Boujelben N. (2009). Removal of nickel and cadmium from aqueous solutions by sewage sludge ash: Study in single and binary systems. Environmental Technology, 30 (6), 561-570.

23. Essington M.E. (2004) Soil and water chemistry: an integrative approach. Boca Raton (FL): CRC Press.

24. Fonseca G.M., de Oliveira M.M., Arakaki L.N.H. (2006). Removal of cadmium, zinc, manganese and chromium cations from aqueous solution by a clay mineral. Journal of Hazardous Materials, 137 (1), 288-292.

25. Font R., Fullana A., Conesa J.A., Llavador F. (2001). Analysis of the pyrolysis and combustion of different sewage sludges by TG. Journal of Analytical and Applied Pyrolysis, 58, 927-941.

26. Gaballah I., Kibertus G. (1998). Recovery of heavy metal ions through decontamination of synthetic solutions and industrial effluents using modified barks. Journal of Geochemistry Exploration, 62, 241-286.

27. Ghodbane I., Nouri L., Hamdaoui O., Chiha M. (2008). Kinetic and equilibrium study for the sorption of cadmium (II) ions from aqueous phase by eucalyptus bark. Journal of Hazardous Materials, $152,148-158$.

28. Gutiérrez-Segura E., Solache-Ríos M., Colín-Cruz A., Fall C. (2012). Adsorption of cadmium by $\mathrm{Na}$ 
and Fe modified zeolitic tuffs and carbonaceous material from pyrolyzed sewage sludge. Journal of Environmental Management, 97, 6-13.

29. Hall K.R., Eagleton L.C., Acrivos A., Vermeulen T. (1966). Pore and solid diffusion kinetics in fixed-bed adsorption under constant pattern conditions. Industrial and Engineering Chemistry Fundamentals, 5, 212-223.

30. Hammaini A., Gonzalez F., Ballester A., Blazquez M.L., Munoz J.A. (2007). Biosorption of heavy metals by activated sludge and their desorption characteristics. Journal of Environmental Management, 84 (4), 419-426.

31. Hawari A.H., Mulligan C.N. (2006). Biosorption of lead (II), cadmium (II), copper (II) and nickel (II) by anaerobic granular biomass. Bioresource Technology, 97 (4), 692-700.

32. Ho Y.S., McKay G. (1999). Pseudo-second order model for sorption processes. Process Biochemistry, $34,451-465$.

33. https://www.giz.de/en/worldwide/41405.html (Last Access Date: 05.03.2020).

34. Ishikawa S., Ueda N., Okumura Y., Iida Y., Baba K. (2007). Recovery of coagulant from water supply plant sludge and its effect on clarification. Journal of Material Cycles and Waste Management, 9 (2), 167-172.

35. Kalavathy M.H., Karthikeyan T., Rajgopal S., Miranda L.R. (2005). Kinetic and isotherm studies of $\mathrm{Cu}(\mathrm{II})$ adsorption onto $\mathrm{H} 3 \mathrm{PO} 4$-activated rubber wood sawdust. Journal of Colloid and Interface Science, 292, 354-362.

36. Katsumata H., Kaneco S., Inomata K., Itoh K., Funasaka K., Masuyama K., Suzuki T., Ohta K. (2003). Removal of heavy metals in rinsing wastewater from plating factory by adsorption with economical viable materials. Journal of Environmental Management, 69, 187-191.

37. Khalfa L., Bagane M. (2011). Cadmium removal from aqueous solution by Tunisian smectitic natural and activated clay: thermodynamic study. Journal of Encapsulation and Adsorption Sciences, 1, 65-71.

38. Li X., Li D., Yan Z., Ao Y. (2018). Adsorption of cadmium by live and dead biomass of plant growth-promoting rhizobacteria. RSC Advances, 8, 33523-33533.

39. Lian L.-S., Yuan L., Chai L.-Y., Min X.-B., Wang Y.-Y., Fang Y., Wang P. (2006). Biosorption behaviors of $\mathrm{Cu} 2+, \mathrm{Zn} 2+, \mathrm{Cd} 2+$ and mixture by waste activated sludge. Transactions of Nonferrous Metals, 16 (6), 1431-1435.

40. Ma L., Wei Q., Chen Y., Song Q., Sun C., Wang Z., Wu G. (2018).Removal of cadmium from aqueous solutions using industrial coal fly ash-Nzvi. Royal Society open science, 5, 171051. http://dx.doi. org/10.1098/rsos.171051.
41. Manahan S.E. (1999a). Chemical Analysis of Water and Wastewater, in: Environmental Chemistry, 7th ed., CRC Press.

42. Manahan S.E. (1999b). Analysis of Wastes and Solids, in: Environmental Chemistry, 7th ed., CRC Press.

43. Masoud M.S., Ali A.E., Elasala G.S. (2015). Synthesis, spectral, computational and thermal analysis studies of metallocefotaxime antibiotics. Spectrochimica Acta Part A, 149, 363-77.

44. Monsalvo V.M., Mohedano A.F., Rodriguez J.J. (2011). Activated carbons from sewage sludge: Application to aqueous-phaseadsorption of 4-chlorophenol. Desalination, 277(1-3), 377-382.

45. Mustafa G., Singh B., Kookana R.S. (2004). Cadmium adsorption and de-sorption behavior on goethite at low equilibrium concentrations: effects of $\mathrm{pH}$ and index cations. Chemosphere, 57, 1325-1333.

46. Nageeb R.M., Soltan M.E., Ahmed M.M., Abdou A.N.E. (2017).Removal of Heavy Metals from Wastewater by New Adsorbents from Chemical Activation of Sewage Sludge. Environmental Engineering Management Journal, 16(7), 1531-1542.

47. Nageeb M.R., Soltan M.E., Ahmed M.M., Abdou A.N.A. (2018). Heavy Metals Removal from Wastewater by Adsorption on Modified Physically Activated Sewage Sludge. Archives of Organic and Inorganic Chemical Sciences, 1 (1), 18-25. DOI: 10.32474/AOICS.2018.01.000102.

48. Otero M., Rozada F., Morán A., Calvo L.F., García A.I. (2009). Removal of heavy metals from aqueous solution by sewage sludge-based sorbents: Competitive effects. Desalination, 239(1-3), 46-57.

49. Patricia A., Alon R., Aitor A., Jose M.K., Iñaki M. (2009). Mechanical Properties of Natural Fibers/ Polyamides Composites. Polymer Composites, 30 (3), 257-264.

50. Phuengprasop T., Sittiwong J., Unob F. (2011). Removal of heavy metal ions by iron oxide coated sewage sludge. Journal of Hazardous Materials, 186, 502-507.

51. Rahimzadeh M.R., Rahimzadeh M.R., Kazemi S., Moghadamnia A.A. (2017). Cadmium toxicity and treatment: An update. Caspian Journal of Internal Medicine, 8(3), 135-145.

52. Rao M.M., Rao G.P., Seshaiah K., Choudary N.V., Wang M.C. (2008). Activated carbon from Ceiba pentandra hulls, an agricultural waste, as an adsorbent in the removal of lead and zinc from aqueous solutions. Waste Management, 28, 849-858.

53. Rashed M.N. (2006) Fruit stones from industrial waste for the removal of lead ions from polluted water. Environmental Monitoring and Assessment, 119 (1-3), 31-41.

54. Rio S., Le Coq L., Faur C., Lecomte D., Le Cloirec P. (2006). Preparation of adsorbents from sewage 
sludge by steam activation for industrial emission treatment. Process Safety and Environmental Protection, 84(4), 258-264.

55. Ros A., Lillo Rodenas M.A., Fuente E., Montes Moran M.A., Martin M.J., Linares-Solano A. (2006). High surface area materials prepared from sewage sludge-based precursors. Chemosphere, 65(1) 132-140.

56. Saygideger S., Gulnaz O., Istifli E.S., Yucel N. (2005). Adsorption of $\mathrm{Cd}$ (II), $\mathrm{Cu}$ (II) and $\mathrm{Ni}$ (II) ions by Lemna minor L.: effect of physicochemical environment. Journal of Hazardous Materials, 126, 96-104.

57. Semerjian L. (2010). Equilibrium and kinetics of cadmium adsorption from aqueous solutions using untreated Pinus halepensis sawdust. Journal of Hazardous Materials, 173, 236-242.

58. Sheha R.R., El-Zahhar A.A. (2008). Synthesis of some ferromagnetic composite resins and their metal removal characteristics in aqueous solutions. Journal of Hazardous Materials, 150, 795-803.

59. Sparks D.L. (1995). Environmental Soil Chemistry. ACADEMIC PRESS, INC. San Diego.

60. Srivastava V.C., Mall I.D., Mishra I.M. (2006). Equilibrium modeling of single and binary adsorption of cadmium and nickel onto bagasse fly ash. Chemical Engineering Journal, 117, 79-91.

61. Vázquez G., Freire M.S., González-Alvarez J., Antorrena G., (2009), Equilibrium and kinetic modeling of the adsorption of $\mathrm{Cd} 2+$ ions onto chestnut shell, Desalination, 249, 855-860.

62. Wang J. (2002). Biosorption of copper (II) by chemically modified biomass of Saccharomyces cerevisiae. Process Biochemistry, 37, 847-850.

63. Wang J., Chen C. (2009). Biosorbents for heavy metals removal and their future. Biotechnology Advances, 27, 195-226.

64. Weber W.J., Morris J.C. (1963). Kinetics of adsorption carbon from solutions. Journal of the Sanitary Engineering Division - American Society of Civil Engineers, 89, 31-60.

65. Weber T.W., Chakravarty R.K. (1974). Pore and solid diffusion models for fixed bed adsorbers. Transactions of the American Institute of Chemical Engineers, 20, 228-238.

66. Weber T., Zanchet A., Brandalise R.N., Crespo J.S., Nunes R.C. (2008). Grinding and Characterization of Scrap Rubbers Powders. Journal of Elastomer and Plastics, 40, 147-159.

67. WHO. (1992). Cadmium. Environmental Health Criteria 134. World Health Organisation, International Programme on Chemical Safety (IPCS), Geneva, Switzerland.

68. WHO. (1993). Guidelines for Drinking Water Quality, Vol. 1. WHO, Geneva.

69. Zhai Y., Wei X., Zeng G., Zhang D., Chu K. (2004). Study of adsorbent derived from sewage sludge for the removal of $\mathrm{Cd} 2+, \mathrm{Ni} 2+$ in aqueous solutions. Separation and Purification Technology, 38 (2), 191-196.

70. Zhou Y.-F., Haynes R.J. (2010). Water treatment sludge can be used as an adsorbent for heavy metals in wastewater streams. WIT Transactions on Ecology and the Environment, 140, 379-389. 